\title{
ANALISIS KEKUATAN VELG ALUMUNIUM MODEL D30D PADA PERUSAHAAN "A"
}

\author{
Sumiyanto dan Abdunnaser \\ Program Studi Teknik Mesin, FTI, Institut Sains Dan Teknologi Nasional \\ Jakarta Selatan, Telp: 021-7270090 \\ Email : sumiyanto@istn.ac.id
}

\begin{abstract}
Wheels are one of the main components in a vehicle. Without wheels of vehicles will not be to function. The damage that occurs in aluminium alloy wheels for the outbreak spoke mostly occur due to a force and tension that occurs exceeds the maximum allowable voltage. With these considerations it is necessary to redesign using $3 D$ software and simulated using finite element method. After simulated, part produce with low pressure casting and machining. Sample part test with several testing as single part such as : life test, drum test, $13^{\circ}$ impact test. After that sample part test as running test such as : curb stone evaluation and rectangle evaluation. The results of sample testing parts such as life test, the drum test, $13^{\circ}$ impact test and running test in the form of curb stone rectangle evaluation and evaluation did not reveal any cracks on the sample part. Nut torque results of sample testing parts such as curb stone evaluation have smaller in $70 \mathrm{~N} . \mathrm{m}$, with allowed limit 61,6 N.m until $88 \mathrm{~N} . \mathrm{m}$. And nut torque results of sample testing parts such as rectangle evaluation have smaller in $76 \mathrm{N.m}$, with allowed limit 61,6 N.m until $88 \mathrm{~N} . \mathrm{m}$
\end{abstract}

Keywords: Wheels, Finite Element Method

\section{PENDAHULUAN}

Velg adalah salah satu komponen utama dalam sebuah kendaraan. Tanpa velg kendaraan tidak akan dapat berjalan. Ada dua jenis material velg yang dikenal di kalangan masyarakat, yaitu velg baja dan velg aluminium. Namun karena beberapa alasan velg baja tidak banyak disukai, salah satunya adalah tidak sesuai dengan perkembangan zaman atau sudah kuno. Disamping itu, velg baja memiliki massa yang lebih berat dari velg alumunium apabila digunakan.

Aspek keselamatan merupakan hal yang wajib diperhitungkan dalam dunia otomotif, karena berhubungan erat dengan nyawa dari pengguna kendaraan tersebut. Sehingga dalam memodifikasi setiap komponennya haruslah dipertimbangkan secara matang. Dalam dunia otomotif telah banyak kecelakaan yang disebabkan oleh velg mobil yang terdeformasi secara plastis. Velg pada sebuah mobil adalah kerangka dari sebuah ban yang menahan gaya dan tegangan akibat dari berat kendaraan dan impact dari permukaan jalan. Impact dari permukaan jalan tersebut dapat mengakibatkan terjadinya tegangan dan deformasi pada velg. Velg aluminium mempunyai daerah yang dinamakan area kritis, dimana area kritis tersebut terdapat pada daerah hub, spoke, dan flange.

Kerusakan yang terjadi pada velg aluminum kebanyakan terjadi karena pecahnya spoke akibat gaya dan tegangan yang terjadi melebihi tegangan maksimum yang diijinkan. Dengan pertimbangan ini maka perlu dilakukan penelitian mengenai pengaruh dari bentuk atau desain spoke terhadap tegangan dan deformasi dengan menggunakan Metode Elemen Hingga. Simulasi secara numerik menggunakan software komputer dapat dilakukan untuk memodifikasi desain dari velg agar kegagalan yang terjadi dapat diminimalisir. Penelitian sebelumnya menjelaskan terkait analisis pengaruh jumlah spoke antara 10, 12, dan 14. Pembuatan model velg dengan menggunakan AutoCAD dan disimulasikan menggunakan software ANSYS 14.0 Workbench yang berbasis Finite Element Method (FEM) atau Metode Elemen Hingga. Hasilnya velg mobil dengan jumlah spoke 10 adalah desain yang paling baik dan optimal dibandingkan dengan desain lainnya. Tegangan maksimum yang terjadi sebesar 52,148 MPa dan deformasi maksimum yang terjadi sebesar $0,5393 \mathrm{~mm}$. Hal ini bisa dijadikan referensi untuk pembuatan desain velg selanjutnya. 
1. Untuk memperoleh nilai distribusi tegangan yang terjadi pada velg aluminium dengan metode elemen hingga.

2. Hasil yang diperoleh digunakan sebagai referensi tambahan untuk mendesain velg mobil selanjutnya.

\section{Teori Pendukung Spesifikasi Velg Mobil}

Terdapat beberapa kode-kode yang dipakai untuk menggambarkan spesifikasi detail dari sebuah velg mobil.

\section{PCD}

PCD adalah singkatan dari "Pitch Circle Diametre". Ini adalah diameter lingkaran yang diambil melalui pusat lubang baut pada velg. PCD diukur dalam millimeter dan juga menunjukkan jumlah baut pada velg. Misalnya kode 5/114,3 merupakan kode untuk menunjukkan jumlah baut pada velg ada 5 dengan PCD 114,3 mm.

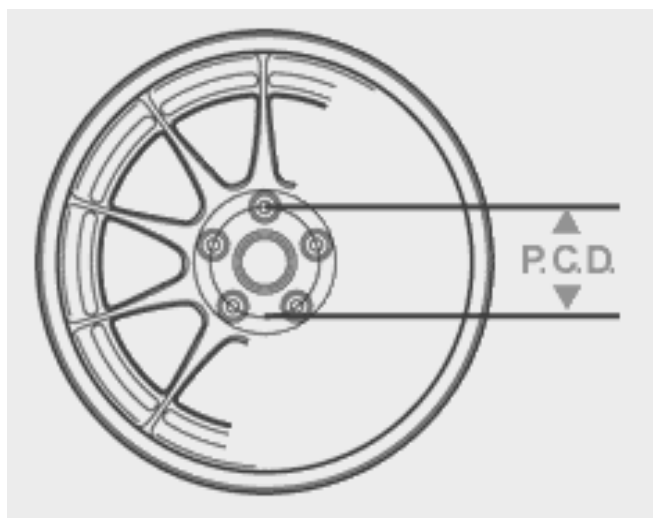

Gambar 1. PCD Velg Mobil

\section{Center Bore}

Merupakan lubang di tengah-tengah lubang baut pada velg mobil, yang berfungsi untuk menahan velg agar tetap berada dipusat roda atau sering juga disebut Centre Hole.

\section{Offset}

Offset adalah ukuran seberapa besar ruang cekungan penampang/permukaan tengah bagian dalam velg. Semakin kecil ukuran offset maka penampang dalamnya semakin tebal, sehingga dapat membuat velg yang terpasang pada mobil akan semakin keluar dari fender.
Offset menunjukkan jarak dari titik tengah velg ke bagian dudukan baut pada as roda (bisa rem cakram atau tutup tromol) yang menggunakan satuan milimeter. Offset disebut dengan "+" (positif) apabila permukaan yang menyentuh dudukan as roda melampaui garis tengah velg, dan disebut "“_" (negatif) apabila lebih dalam daripada garis tengah velg. Pemilihan jenis offset ini perlu diperhatikan agar ban tidak terlalu masuk dan menyentuh rongga spatbor mobil atau dapat menyentuh kaliper rem.

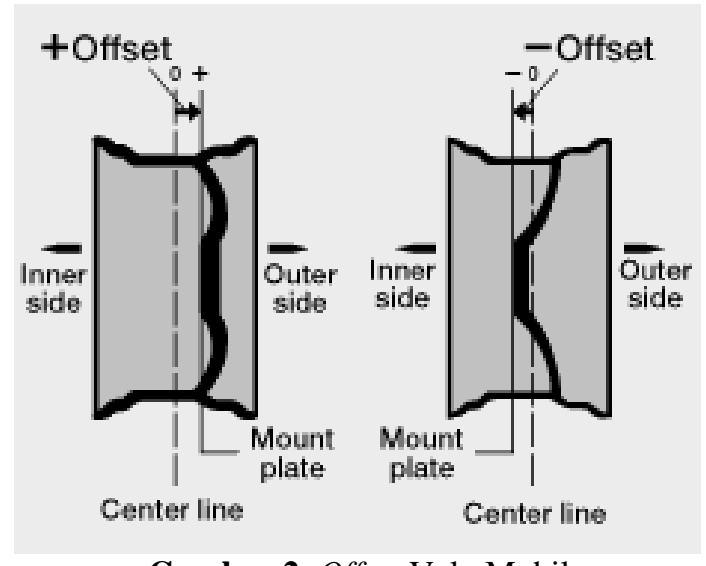

Gambar 2. Offset Velg Mobil

\section{Rim Marking}

Berfungsi untuk menunjukan ukuran dari velg. Pada umumnya format penulisannya adalah 18x8J ET 35, yang artinya velg mobil tersebut berukuran diameter 18 inch dengan lebar velg 8 inch dan offset $35 \mathrm{~mm}$.

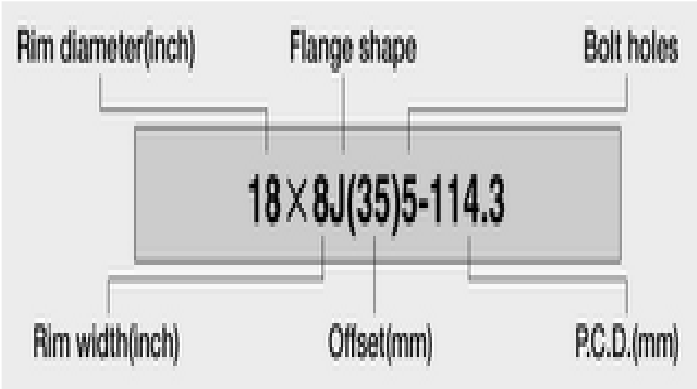

Gambar 3. Contoh Ukuran Velg Mobil

\section{Aplikasi Aluminium Pada Velg Mobil}

Velg adalah komponen utama dalam sebuah mobil. Tanpa velg, mobil tidak akan dapat berjalan. Velg aluminum sendiri ada dua jenis yang dikenal di kalangan masyarakat yaitu velg aluminium standar dan velg aluminium jenis polish.

Velg aluminium standar atau velg dari pabrikan sekarang ini banyak yang kurang 
menyukai karena beberapa alasan, salah satunya adalah masalah trend. Oleh karena itu banyak yang menggantinya dengan velg yang lebih gaya atau yang disebut dengan velg polish.

\section{Metode Elemen Hingga (Finite Element Method)}

Metode elemen hingga atau biasa disebut Finite Element Method (FEM) pada awalnya merupakan kebutuhan untuk memecahkan permasalahan analisis yang kompleks serta masalah struktural dibidang sipil dan aeronautical engineering. FEM adalah salah satu metode numerik yang paling banyak dipakai didunia engineering (sipil, mesin, penerbangan, mikro elektronik, bio engineering dan material). Metode ini berusaha memecahkan partial differential equations dan persamaan integrasi lainnya yang dihasilkan dari hasil diskritisasi benda kontinum. Meski berupa pendekatan, metode ini dikenal cukup ampuh memecahkan struktur-struktur yang kompleks dalam analisis mekanika benda padat (solid mechanics). Saat ini banyak sekali software FEM yang beredar, contohnya adalah MSC, ABAQUS, ANSYS dan LSDYNA.

Metode yang lain adalah metode analitik, untuk melakukannya diperlukan suatu persamaan matematik yang merupakan model dari perilaku fisik. Semakin rumit perilaku fisiknya (karena kerumitan bentuk geometri, banyaknya interaksi beban, constrain, sifat material dan lain-lain) maka semakin sulit atau bahkan mustahil dibangun suatu model matematik yang dapat mewakili permasalahan tersebut. Alternatif metodenya adalah dengan cara membagi menjadi bagianbagian kecil yang sederhana yang mana pada bagian kecil tersebut kita bisa membangun model matematik dengan lebih sederhana. Kemudian interaksi antar bagian kecil tersebut ditentukan berdasarkan fenomena fisik yang akan diselesaikan. Metode ini dikenal sebagi metode elemen hingga, karena kita membagi permasalahan menjadi sejumlah elemen tertentu (finite) untuk mewakili permasalah yang sebenarnya dengan jumlah elemennya adalah tidak berhingga. Dengan kecanggihan perangkat lunak (software) dan perangkat keras (hadrware) komputer sekarang, masalah rekayasa yang rumit dapat dimodelkan dengan relatif mudah, dan waktu yang diperlukan untuk memecahkan problem pun semakin singkat.

\section{METODOLOGI PENELITIAN}

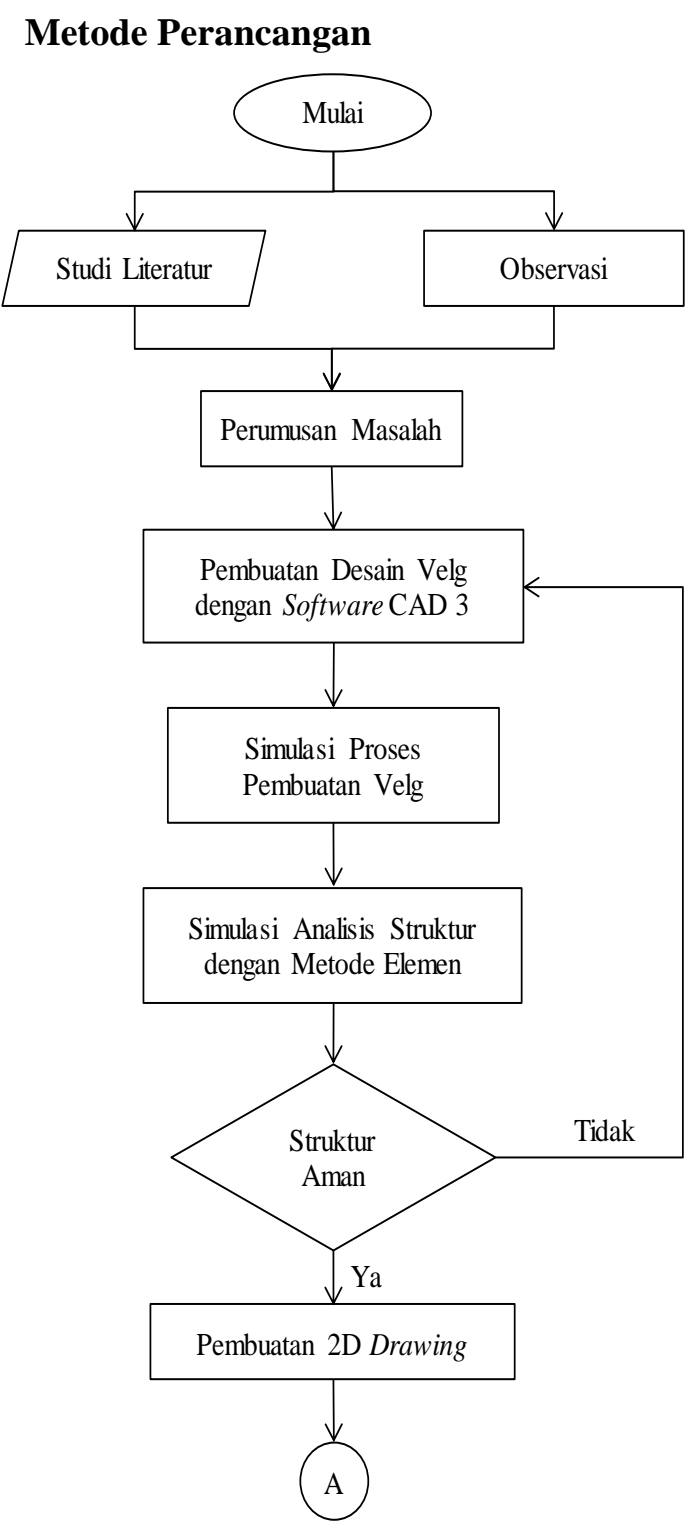




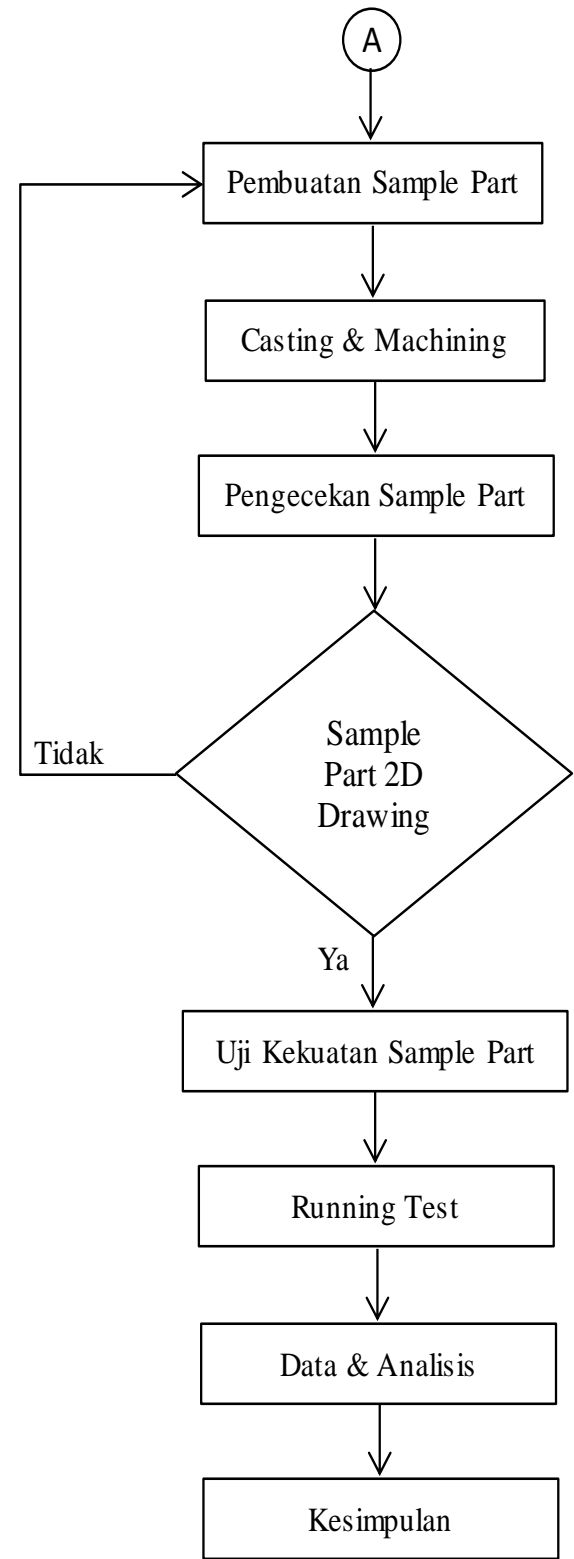

Gambar 4. Diagram Alir Penelitian

\section{Material yang Digunakan}

Dalam merancang suatu struktur, ditetapkan prosedur pemilihan suatu material yang sesuai dengan kondisi aplikasinya. Untuk pemilihan material sendiri mengacu pada jenis material yang ada di pasaran, sehingga nantinya tidak ada kesulitan dalam proses pembuatan, namun tidak mengesampingkan faktor dari kekuatan, kekerasan dan ketangguhan dalam penetapan pemilihan suatu material. Dalam penelitian ini material yang digunakan yaitu aluminium paduan dengan spesifikasi atau standard minium paduan seperti yang tertera pada tabel 1 .
Tabel 1. Spesifikasi Minimum Material yang Digunakan

\begin{tabular}{|c|c|c|c|c|c|c|c|}
\hline \multirow{2}{*}{ No } & \multirow{2}{*}{$\begin{array}{l}\text { Chemical } \\
\text { Code }\end{array}$} & \multirow{2}{*}{$\begin{array}{c}\text { Composition } \\
\text { (\%) }\end{array}$} & \multicolumn{2}{|c|}{ Heat Treatment } & \multirow{2}{*}{\begin{tabular}{|c|} 
Tensile \\
Strength \\
(MPa)
\end{tabular}} & \multirow{2}{*}{$\begin{array}{c}\text { Elongation } \\
(\%)\end{array}$} & \multirow{2}{*}{\begin{tabular}{|c|} 
Brinell \\
Hardness of \\
Permanent \\
Mold
\end{tabular}} \\
\hline & & & \begin{tabular}{|c|} 
Solution \\
Treatment \\
\end{tabular} & Tempering & & & \\
\hline 1 & $\mathrm{Cu}$ & $0.2 \max$ & \multirow{12}{*}{$\begin{array}{c}\text { Approx. } \\
520^{\circ} \mathrm{C} \\
\text { Approx. } 3 \mathrm{~h}\end{array}$} & \multirow{12}{*}{$\begin{array}{c}\text { Approx. } \\
170^{\circ} \mathrm{C} \\
\text { Approx. } 4 \mathrm{~h}\end{array}$} & \multirow{12}{*}{$225 \min$} & \multirow{12}{*}{$3 \mathrm{~min}$} & \multirow{12}{*}{ Approx. 85} \\
\hline 2 & $\mathrm{Si}$ & $6.5-7.5$ & & & & & \\
\hline 3 & $\mathrm{Mg}$ & $0.2-0.8$ & & & & & \\
\hline 4 & $\mathrm{Zn}$ & $0.3 \max$ & & & & & \\
\hline 5 & $\mathrm{Fe}$ & $0.5 \max$ & & & & & \\
\hline 6 & $\mathrm{Mn}$ & $0.5 \max$ & & & & & \\
\hline 7 & $\mathrm{Ni}$ & $0.1 \max$ & & & & & \\
\hline 8 & $\mathrm{Ti}$ & $0.2 \max$ & & & & & \\
\hline 9 & $\mathrm{~Pb}$ & $0.1 \mathrm{mzx}$ & & & & & \\
\hline 10 & Sn & $0.05 \max$ & & & & & \\
\hline 11 & $\mathrm{Cr}$ & $0.1 \max$ & & & & & \\
\hline 12 & $\mathrm{Al}$ & Remainder & & & & & \\
\hline
\end{tabular}

\section{Pembuatan Model}

Setelah diketahui tipe velg dan tampilan muka yang akan digunakan, selanjutnya dibuat model velg tersebut dengan menggunakan bantuan software CAD 3 dimensi. Namun pada pembuatan model tidak hanya sekali jadi, tetapi terdapat beberapa revisi pada pembuatan model tersebut sehingga nantinya velg tersebut benar-benar sesuai dengan yang diinginkan. Desain akhir dari velg dapat dilihat pada gambar 5.

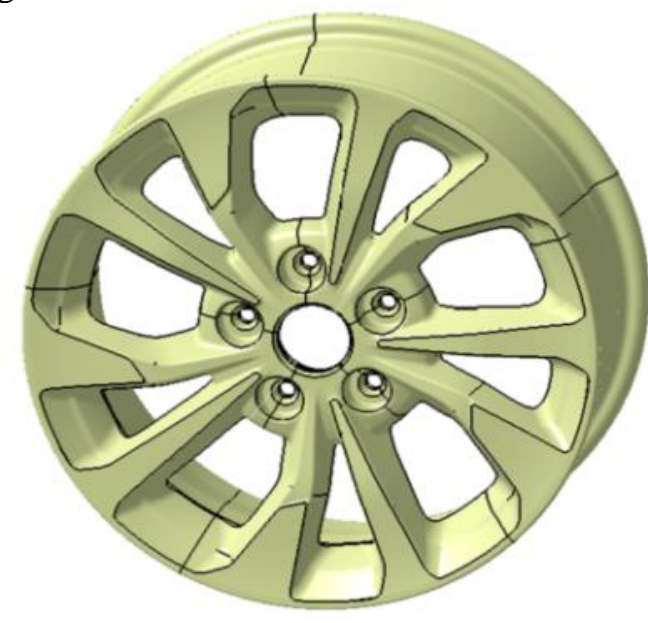

Gambar 5. Desain Akhir Velg

\section{HASIL DAN PEMBAHASAN}

\section{Simulasi Pembuatan}

Setelah didapatkan desain akhir velg, selanjutnya dilakukan simulasi pembuatan velg dengan metode casting menggunakan software. Hal ini bertujuan untuk mengurangi kesalahan saat proses pembuatan nantinya. 


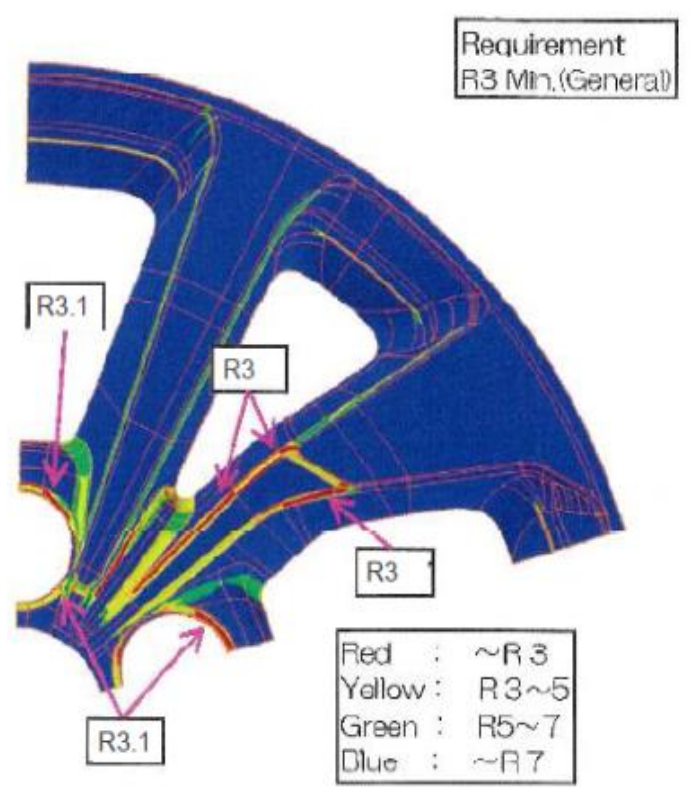

Gambar 6. Maximum Radius Velg

Pada gambar 6 kita dapat mengetahui bahwa minimum radius yang diperbolehkan sebesar $3 \mathrm{~mm}$, beberapa sudut dari velg menunjukan warna merah namun masih dalam batas yang diperbolehkan.

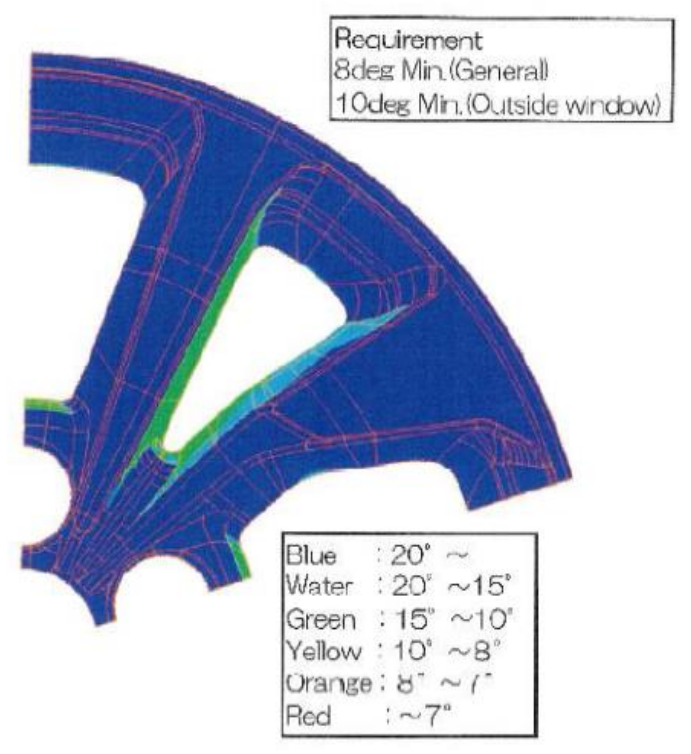

Gambar 7. Maximum Draft Angle Velg

Pada gambar 7 menunjukan draft angle dari desain velg tersebut masih dalah batas toleransi yang diperbolehkan.

Desain velg yang digunakan merupakan tipe velg aluminium dengan finishing permukaan menggunakan proses diamond cut. Oleh karena itu dibutuhkan juga simulasi untuk proses tersebut.

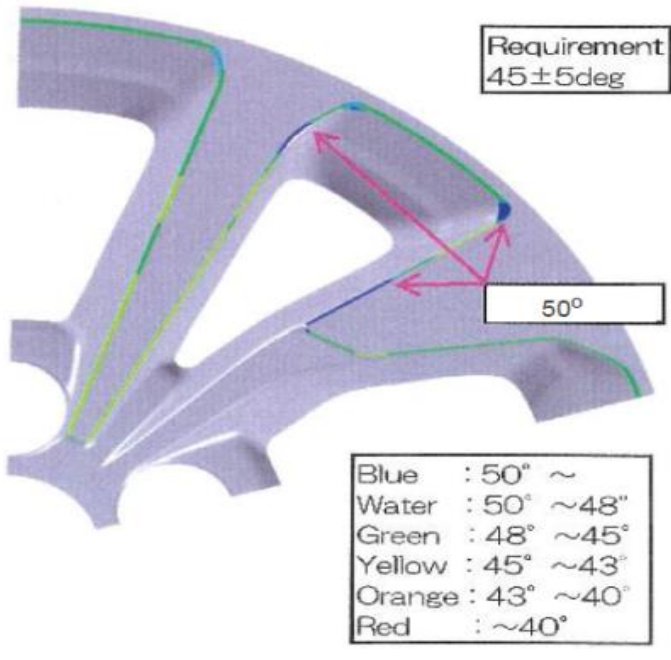

Gambar 8. Draft Angle at the Diamond Cut Edge Portion

Dari gambar 8 didapatkan hasil simulasi dari permukaan velg dengan finishing menggunakan metode diamond cut, hasilnya desain velg masih dalam batas toleransi.

\section{Simulasi Numerik Velg Mobil}

Pada simulasi numerik dengan metode elemen hingga sesuai dengan standard JWL (Japan Light Alloy Wheels) sebuah velg sebelum diproduksi minimal harus dilakukan pengetesan berupa life test, drum test dan $13^{\circ}$ impact test. Dari ketiga tes tersebut nantinya didapatkan tegangan dan regangan maksimum yang akan terjadi pada velg.

\section{Life Test}

Pada simulasi pengetesan ini sesuai dengan standard JWL, velg akan diberikan beban berupa momen pada area nut seperti pada gambar 9.

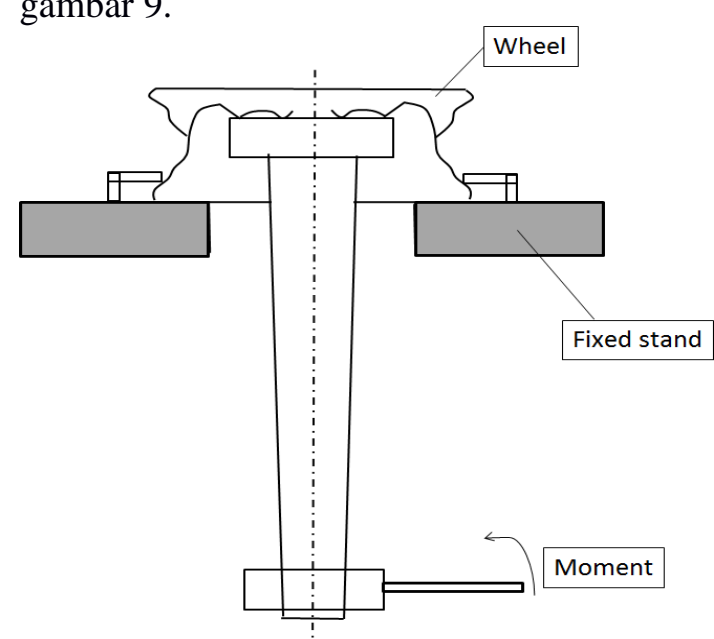

Gambar 9. Life Test pada Velg : 2857 N.m. 
Jumlah Pembebanan $\quad: 300.000$ kali.

Tingtening Nut : 103 N.m

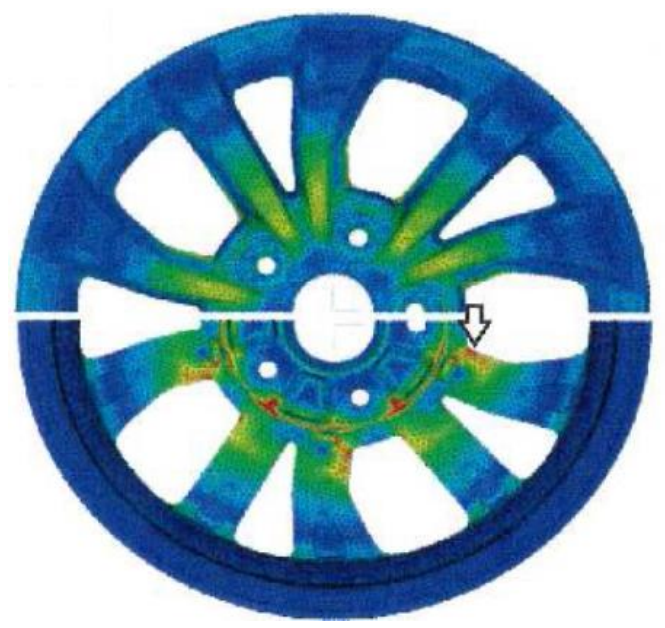

Gambar 10. Tegangan Maksimum pada Simulasi Life Test

Dari gambar 10 didapatkan nilai tegangan maksimum pada simulasi life test terletak pada bagian spoke bottom. Detail hasil simulasi life test ditujukan pada tabel 2 .

Tabel 2. Hasil Simulasi Life Test

\begin{tabular}{|c|c|c|c|c|}
\hline Item & Area & $\begin{array}{l}\text { Target } \\
\text { (Mpa) }\end{array}$ & $\begin{array}{l}\text { Hasil } \\
\text { (Mpa) }\end{array}$ & Judge \\
\hline Life Test & Bolthole & \multirow{4}{*}{$0<225$} & 44 & \multirow{4}{*}{ OK } \\
\hline$M=2857 \mathrm{~N} . \mathrm{m}$ & Spoke top & & 60 & \\
\hline \multirow[t]{2}{*}{$N>30 \times 10^{\wedge} 3 \mathrm{rev}$} & Spoke bottom & & 91 & \\
\hline & Root & & 37 & \\
\hline
\end{tabular}

\section{Drum Test}

Sesuai dengan standard JWL. Pada simulasi pengetesan ini velg di simulasikan mendapat tekanan dari area luar seperti pada gambar 11.

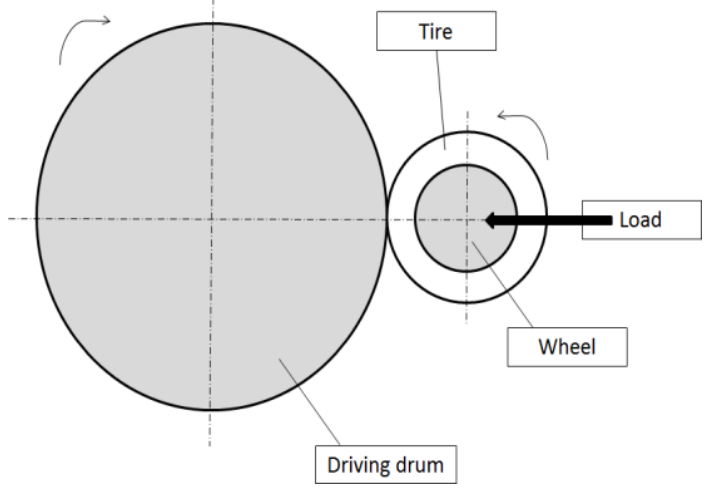

Gambar 11. Drum Test pada Velg

Load : $20594 \mathrm{~N}$.

Jumlah Pembebanan : 1.500 .000 kali.

\section{Tingtening Nut $\quad: 103$ N.m}

Tekanan Ban : $451 \mathrm{kPa}$.

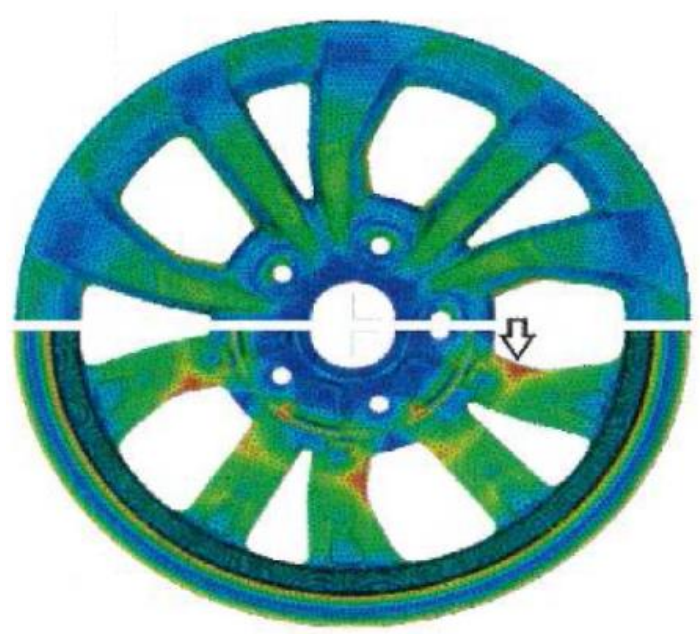

Gambar 12. Tegangan Maksimum pada Simulasi Drum Test

Dari gambar 12 didapatkan nilai tegangan maksimum pada simulasi drum test terletak pada bagian spoke bottom. Detail hasil simulasi drum test ditunjukan pada tabel 3 .

Tabel 3. Hasil Simulasi Drum Test

\begin{tabular}{|c|c|c|c|c|}
\hline Item & Area & $\begin{array}{l}\text { Target } \\
\text { (Mpa) }\end{array}$ & $\begin{array}{l}\text { Hasil } \\
\text { (Mpa) }\end{array}$ & Judge \\
\hline \multirow{4}{*}{$\begin{array}{l}\text { Drum Test } \\
P=20594 \mathrm{KN} \\
N>150 \times 10^{\mathrm{M}} 4 \text { cycle }\end{array}$} & Bolthole & \multirow{4}{*}{$0<225$} & 32 & \multirow{4}{*}{ OK } \\
\hline & Spoke top & & 53 & \\
\hline & Spoke bottom & & 87 & \\
\hline & Root & & 45 & \\
\hline
\end{tabular}

\section{$13^{\circ}$ Impact Test}

Pada simulasi pengetesan ini posisi velg dimiringkan sebesar $13^{\circ}$ untuk memperoleh kondisi paling ekstrim ketika velg mengalami sebuah benturan.

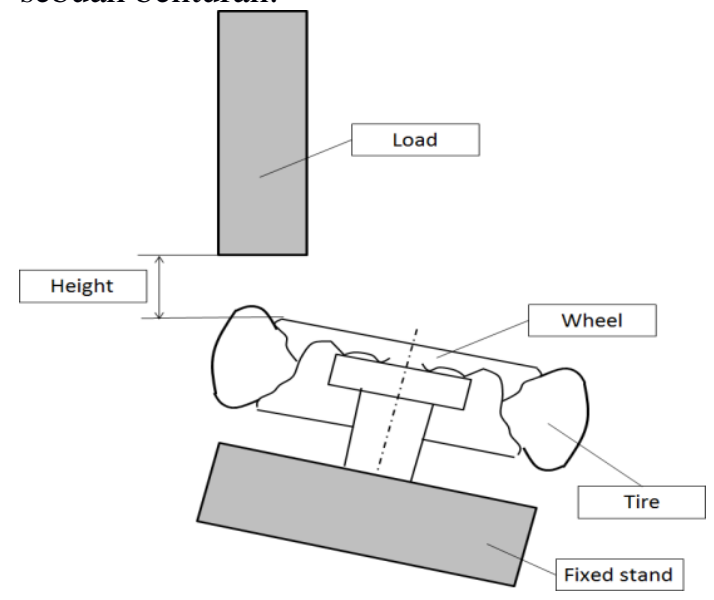

Gambar 13. Impact Test pada Velg

Berat Beban : $660 \mathrm{~kg}$.

Ketinggian $: 230 \pm 2 \mathrm{~mm}$. 
Tekanan Ban $\quad$ : $451 \mathrm{kPa}$.

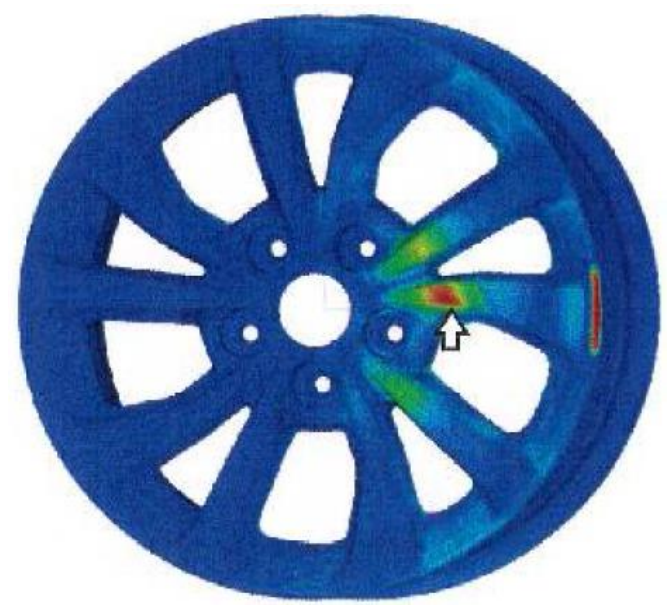

Gambar 14. Regangan Maksimum pada Simulasi $13^{\circ}$ Impact Test

Dari gambar 14 didapatkan nilai regangan maksimum pada simulasi drum test terletak pada bagian spoke top. Detail hasil simulasi drum test ditunjukan pada tabel 4.

Tabel 4. Hasil Simulasi $13^{\circ}$ impact test

\begin{tabular}{|c|c|c|c|c|}
\hline Item & Area & $\begin{array}{c}\text { Target } \\
(\%)\end{array}$ & $\begin{array}{l}\text { Hasil } \\
(\%)\end{array}$ & Judge \\
\hline \multirow{4}{*}{$\begin{array}{l}13^{\circ} \mathrm{Impact} \text { test } \\
\mathrm{m}=660 \mathrm{~kg} \\
h=230 \mathrm{~mm}\end{array}$} & Bolthole & \multirow{4}{*}{$\delta<3$} & 0.7 & \multirow{4}{*}{ OK } \\
\hline & Spoke top & & 2.0 & \\
\hline & Spoke bottom & & 1.9 & \\
\hline & Root & & 1.2 & \\
\hline
\end{tabular}

\section{Proses Pembuatan Sample Part}

Proses pembuatan velg dilakukan dengan metode casting dan permukaan akhir dari velg di polish menggunakan diamond cut untuk mendapatkan tampilan mengkilat dari velg tersebut. Berikut flow proses pembuatan velg aluminium :

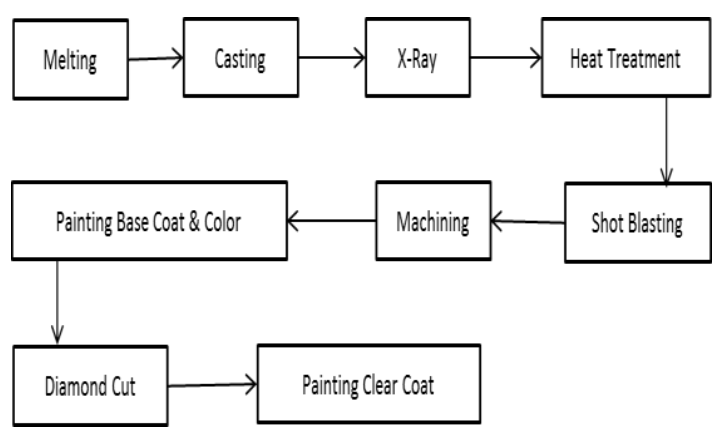

Gambar 15. Diagram Alir Pembuatan Velg Diamond Cut

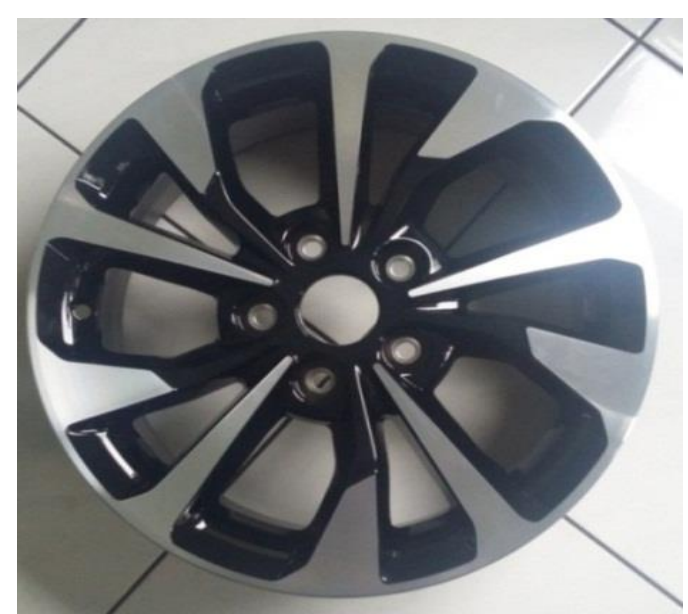

Gambar 16. Sample Part Velg Diamond Cut

\section{Verifikasi Simulasi Sample Part}

Setelah sample part dinyatakan sesuai dengan permodelan, selanjutnya dilakukan pengetesan untuk memverifikasi velg yang sudah dibuat. Hal ini bertujuan untuk mengetahui kekuatan actual dari velg tersebut dan juga sebagai acuan bahwa velg tersebut layak untuk diproduksi massal.

\section{Life Test}

Seperti yang sudah dilakukan pada simulasi numerik, selanjutnya sample part diuji life test sesuai dengan standard JWL. Velg akan diberikan beban berupa momen pada area nut, berikut standard parameter input yang harus diberikan pada velg :

$\begin{array}{ll}\text { Moment } & : 2857 \text { N.m. } \\ \text { Jumlah Pembebanan } & : 300.000 \text { kali } \\ \text { Tingtening Nut } & : 103 \text { N.m }\end{array}$

Kriteria hasil pengetesan ini adalah velg tidak boleh ditemukan adanya retak sedikitpun setelah dilakukan pengetesan.

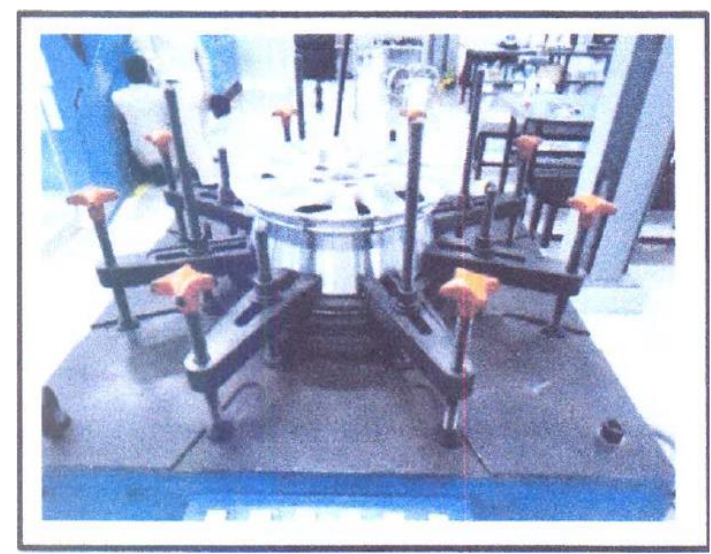

Gambar 17. Actual Life Test 

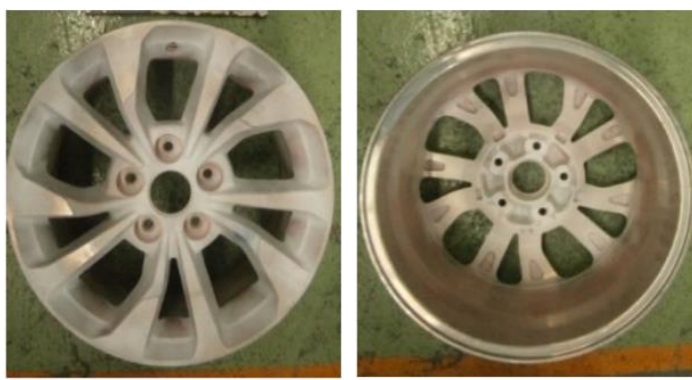

Gambar 18. Sample Part Setelah Life Test

Setelah diberikan beban sebanyak 300.000 kali secara berturut-turut, hasilnya tidak ditemukan retak pada sample part, sample part dinyatakan $\mathrm{OK}$.

\section{Drum Test}

Parameter drum test sama dengan yang sudah dilakukan waktu simulasi, sesuai dengan standard JWL. Pada pengetesan ini velg mendapat tekanan dari area luar, berikut standard parameter input yang harus diberikan pada velg :
Load
: $20594 \mathrm{~N}$.
Jumlah Pembebanan
: $1.500 .000 \mathrm{kali}$
Tingtening Nut
: 103 N.m
Tekanan Ban
: $451 \mathrm{kPa}$.

Kriteria hasil pengetesan ini adalah velg tidak boleh ditemukan adanya retak sedikitpun setelah dilakukan pengetesan.

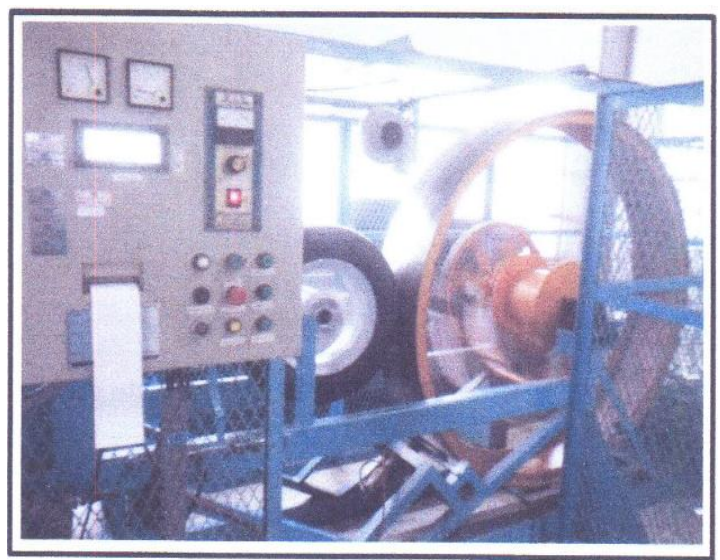

Gambar 19. Actual Drum Test
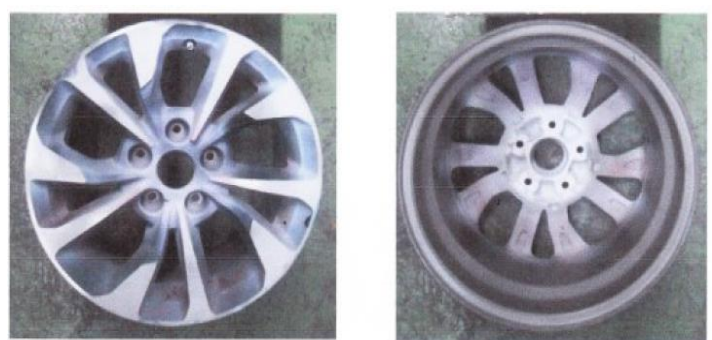

Gambar 20. Sample Part setelah Drum Test
Setelah diberikan beban sebanyak 1.500 .000 kali secara berturut-turut, hasilnya tidak ditemukan retak pada sample part, sample part dinyatakan OK.

\section{$13^{\circ}$ Impact Test}

Pada pengetesan ini posisi velg dimiringkan sebesar $13^{\circ}$ untuk memperoleh kondisi paling ekstrim ketika velg mengalami sebuah benturan, berikut standard parameter input yang harus diberikan pada velg :

$\begin{array}{ll}\text { Berat Beban } & : 660 \mathrm{~kg} . \\ \text { Ketinggian } & : 230 \pm 2 \mathrm{~mm} . \\ \text { Tekanan Ban } & : 451 \mathrm{kPa} .\end{array}$

Kriteria dari pengetesan tersebut adalah sample tidak boleh ditemukan adanya retak sedikitpun setelah dilakukan pengetesan. Pada pengetesan ini diambil 3 data dari masing-masing velg, hal tersebut bertujuan untuk mendapatkan hasil benturan dari beberapa sisi velg.

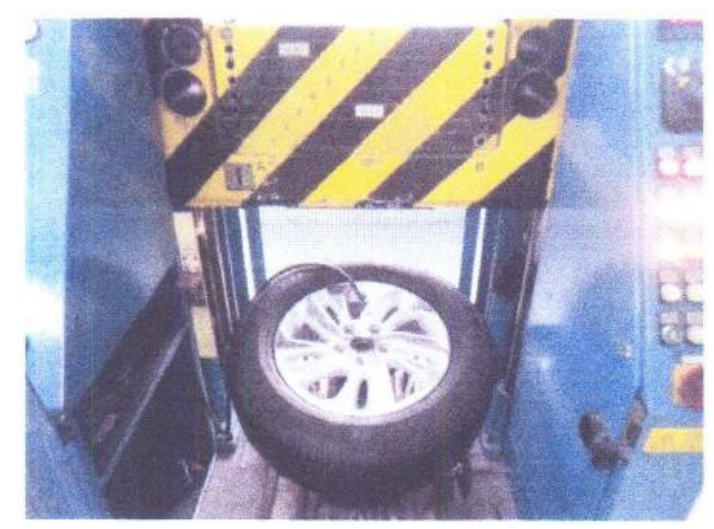

Gambar 21. Actual $13^{\circ}$ Impact Test
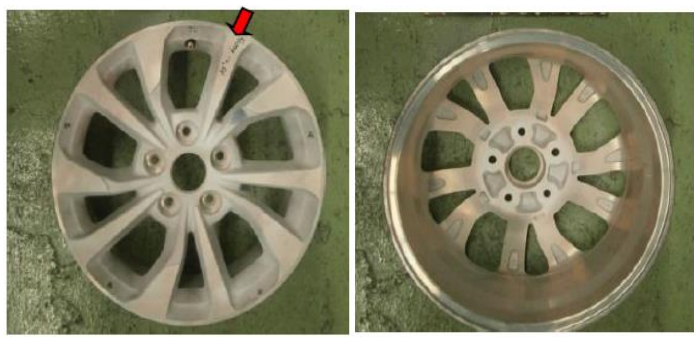

Gambar 22. Sample Part ke 2 setelah $13^{\circ}$ Impact Test

\section{$90^{\circ}$ Impact Test}

Pada pengetesan ini posisi velg vertikal untuk memperoleh kondisi normal ketika velg dipasang pada mobil.

$\begin{array}{ll}\text { Berat Beban } & : 1010 \mathrm{~kg} . \\ \text { Ketinggian } & : 11 \text { inch. } \\ \text { Tekanan Ban } & : 451 \mathrm{kPa} .\end{array}$


Kriteria dari pengetesan tersebut adalah velg tidak boleh ditemukan adanya retak sedikitpun setelah dilakukan pengetesan.

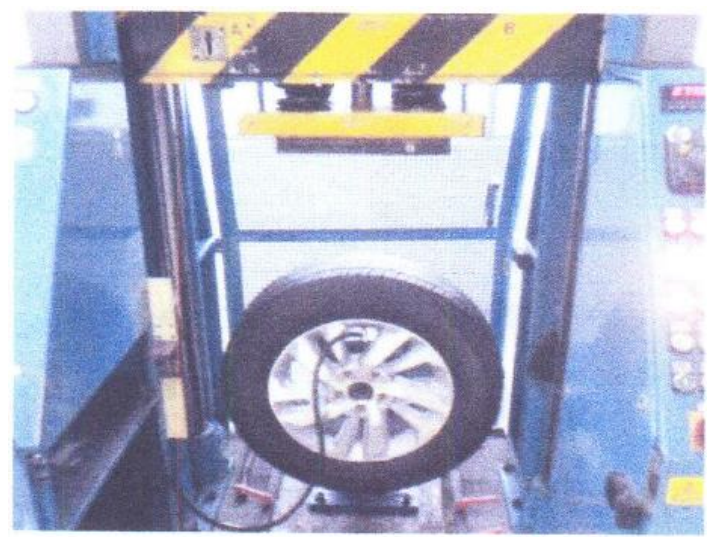

Gambar 23. Actual $90^{\circ}$ Impact Test
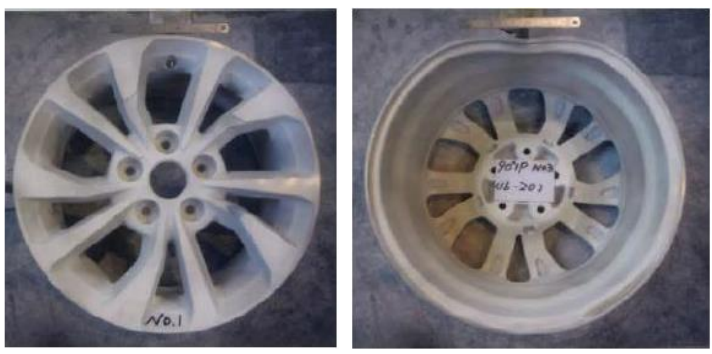

Gambar 23. Sample Part setelah $90^{\circ}$ Impact Test

\section{Nut Seat Over Tightening Test}

Pada pengetesan ini mensimulasikan kondisi dimana ketika pengguna memasang nut pada velg namun melebihi dari standard. Standard pemasangan nut sendiri adalah 103 N.m, namun pada pengetesan ini nut dipasang hingga 186 N.m. Pada pengetesan ini kondisi velg tidak boleh terjadi retak.

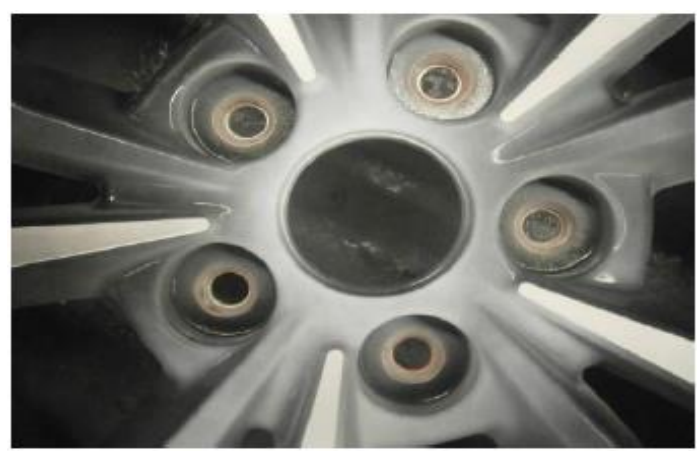

Gambar 24. Sample Part setelah Nut Seat Over Tightening Test

\section{Running Test (Crash Test)}

Setelah dilakukan pengetesan pada sample part dan sudah dinyatakan OK, langkah selanjutnya adalah melakukan running test untuk verifikasi terakhir sebelum velg tersebut dinyatakan layak untuk diproduksi.

\section{Curb Stone Evaluation}

Metode pengetesan untuk melakukan tes ini adalah velg dipasang pada mobil dan dilakukan tes tabrak, berikut detail metode dari pengetesan tersebut :

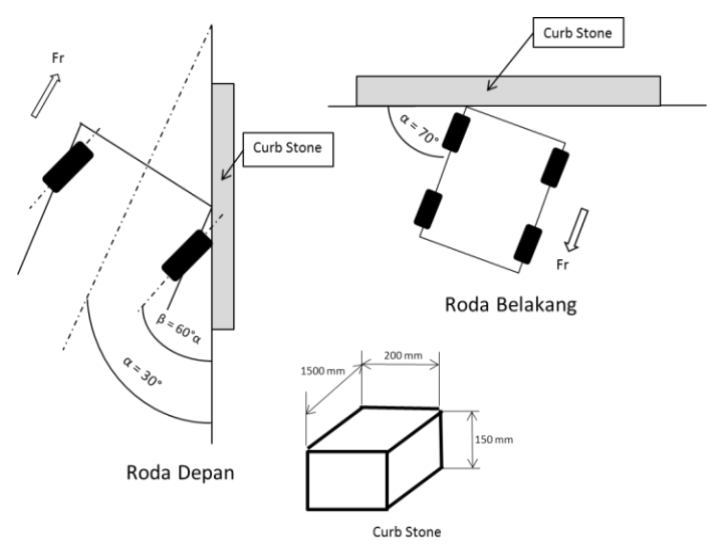

Gambar 25. Detail Metode Curb Stone Evaluation

Parameter pengujian :

a. Mobil dijalankan dengan kecepatan $10 \pm 5$ $\mathrm{km} / \mathrm{jam}$.

b. Nut dipasang dengan toleransi paling bawah sebesar 88 N.m.

c. Tekanan ban $230 \mathrm{kPa}$.

d. Total benturan 20 kali masing-masing ban.

Hasil pengetesan curb stone evaluation dapat dilihat pada gambar dibawah ini :

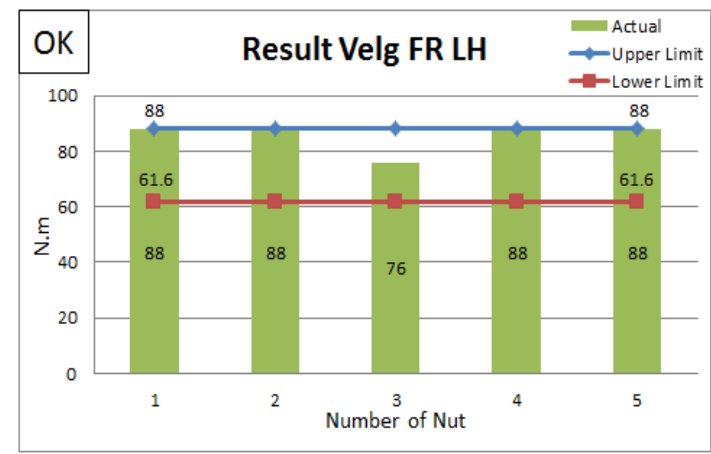

Gambar 26. Grafik Result Velg FR LH

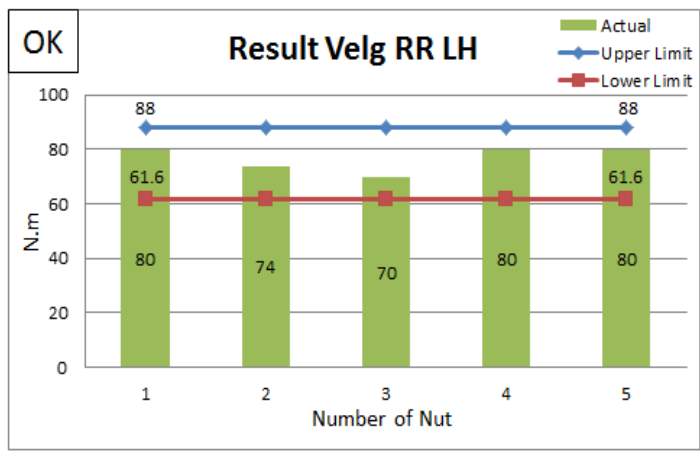

Gambar 27. Grafik Result Velg RR LH 


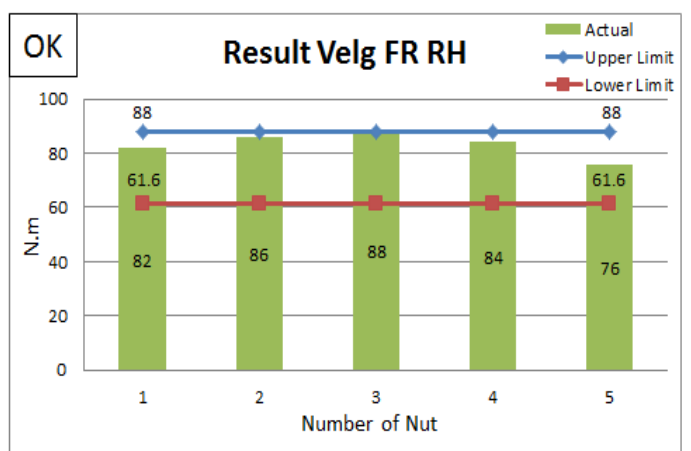

Gambar 28. Grafik Result Velg FR RH

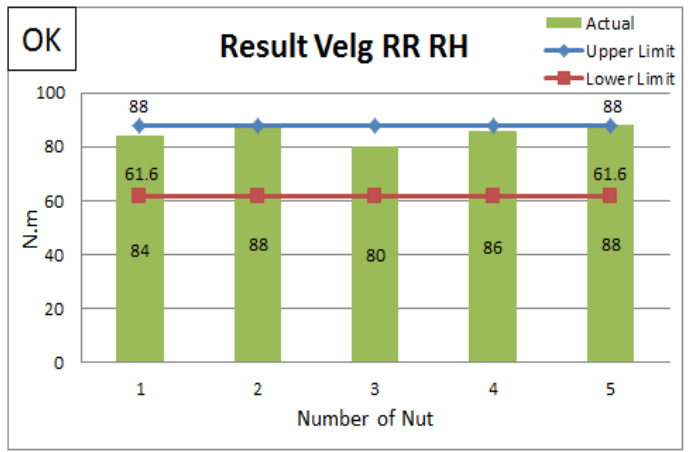

Gambar 29. Grafik Result Velg RR RH

Dari hasil pengetesan tersebut didapatkan bahwa ada penurunan torque pada beberapa nut, namun hasil tersebut masih masuk dalam standard. Terkait retak dan perubahan bentuk pada velg, tidak ditemukan hal tersebut pada masing-masing velg tersebut, sehingga velg tersebut dinyatakan $\mathrm{OK}$.

\section{Rectangle Evaluation}

Metode pengetesan untuk melakukan test ini adalah velg dipasang pada mobil dan dilakukan tes tabrak, berikut detail metode dari pengetesan tersebut :

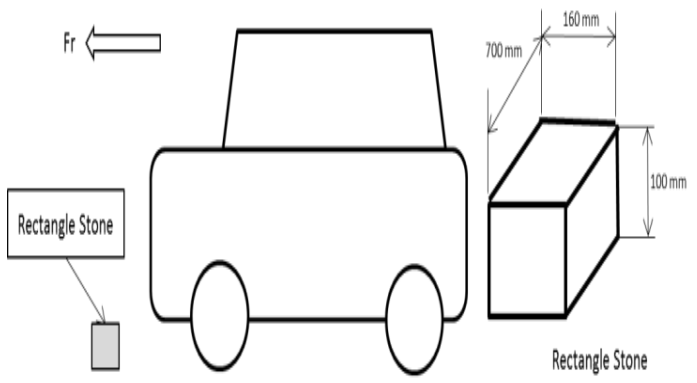

Gambar 30. Detail Metode Rectangle Evaluation

Parameter pengujian :

a. Mobil dijalankan hingga kecepatan mencapai $40 \mathrm{~km} / \mathrm{jam}$.

b. Tepat sebelum terjadinya tabrakan, transmisi dikembalikan kekondisi netral. c. Nut dipasang dengan toleransi paling bawah sebesar 88 N.m.

d. Tekanan ban $230 \mathrm{kPa}$.

e. Total benturan 10 kali pada masingmasing ban.

Hasil pengetesan rectangle evaluation dapat dilihat pada gambar dibawah ini :

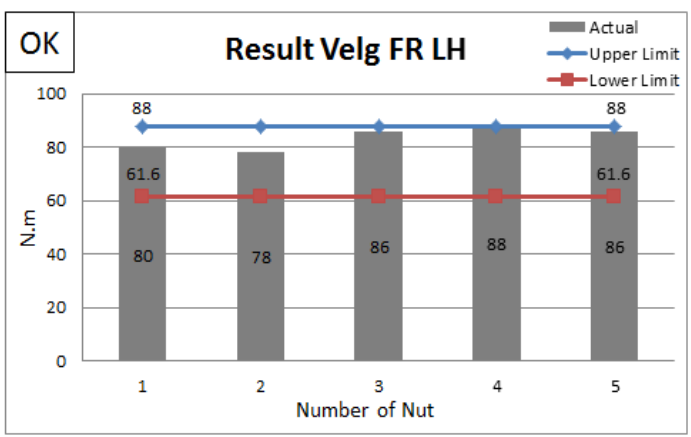

Gambar 31. Grafik Result Velg FR LH

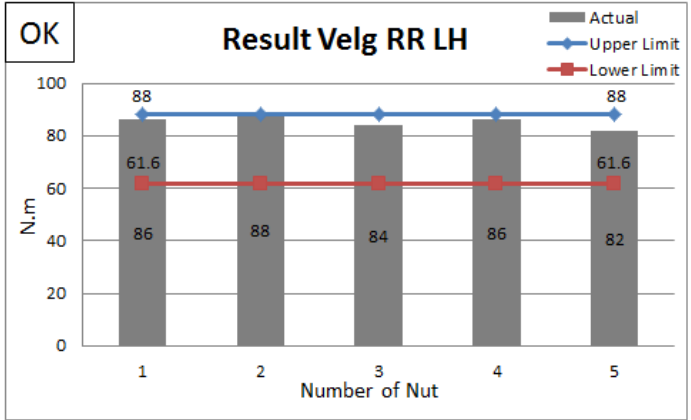

Gambar 32. Grafik Result Velg RR LH

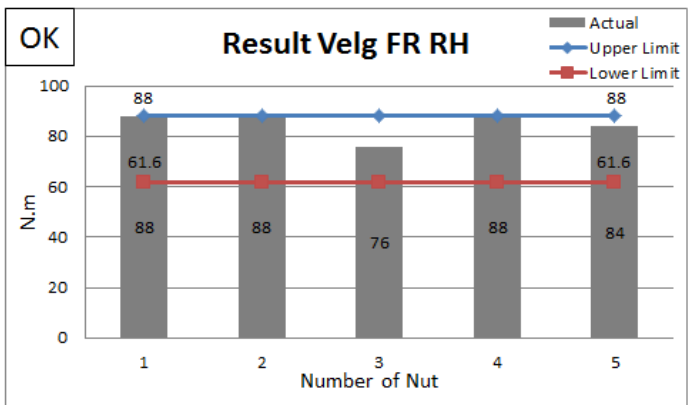

Gambar 33. Grafik Result Velg FR RH

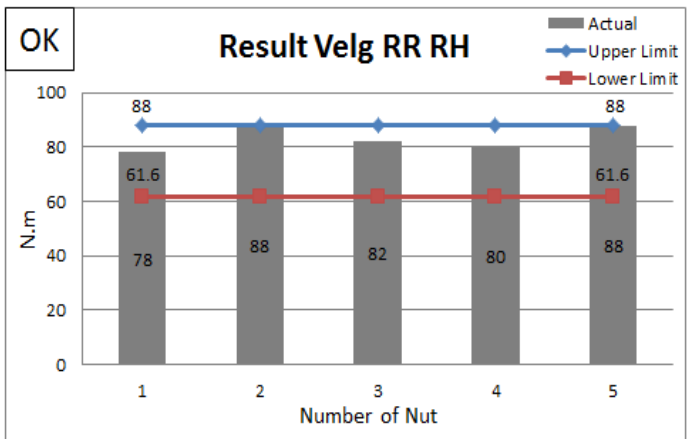

Gambar 34. Grafik Result Velg RR RH

Seperti pada Curb Stone Evaluation dari hasil pengetesan tersebut didapatkan bahwa ada penurunan torque pada beberapa nut, namun 
hasil tersebut masih masuk dalam standard. Terkait retak dan perubahan bentuk pada velg, tidak ditemukan hal tersebut pada masing-masing velg tersebut, sehingga velg tersebut dinyatakan $\mathrm{OK}$.

\section{KESIMPULAN}

1. Dari hasil pengujian yang telah dilakukan, ada beberapa hal yang perlu diperhatikan dari segi design untuk memperoleh distribusi tegangan yang terjadi pada velg aluminium dengan metode elemen hingga, antara lain :

a. Minimum radius velg yang diijinkan adalah $3 \mathrm{~mm}$

b. Minimum draft angle untuk proses casting yang diijinkan adalah $7^{\circ}$

c. Minimum draft angle untuk proses diamond cut yang diijinkan adalah $45^{\circ} \pm 5^{\circ}$

2. Hasil dari pengetesan sample part menggunakan metode life test, drum test, $13^{\circ}$ impact test, curb stone evaluation, dan rectangle evaluation tidak ditemukan adanya retak pada sample part sehingga pengujian dinyatakan "OK". Metode pengujian ini dapat digunakan sebagai referensi tambahan untuk membuat / mendesain velg mobil selanjutnya.

\section{DAFTAR PUSTAKA}

1. Anggono, Wilyanto. 2011. Deciding the Optimum Spoke Number of Motor Cycle Cast Wheel. Seminar Nasional Simulasi Velg. IX (2). 1-5.

2. Pringgo. 2008. Arti Kode Velg. http://www.jipku.com. Diakses pada tanggal 29 April 2017

3. Daryanto. 2009. Reparasi Casis Mobil. Bina Adiaksara. Jakarta.

4. Sifat Fisik Aluminium. http://id.wikipedia.org. Diakses pada tanggal 2 July 2017.

5. Hatch, John E., 2010. Aluminium Properties and Physical Metallurgy. Ohio: American Society for Metals.

6. A.Schey, John. 2009. Proses Manufaktur. Edisi ketiga. Yogyakarta: Penerbit Andi.

7. Joseph, Edward Shingley, Mechanical Engineering Design. MC Graw Hill.

8. James W. Dally, William F. Rally, 2008. Experimental Stress Analisis, 3rd Edition.

9. S, Purwantini, Elly. 2012. Pemodelan Temperatur Ruang Menggunakan Regresi Non Linier Berdasarkan Hasil Estimasi FEM 3-D Linier. Journal Program Studi Teknik Elektronika, Departemen Elektro Politeknik Elektronika Negeri Surabaya Negeri Surabaya.

10. Harri. 2009. Desain Dan Analisis Velg Mobil Berbasis Aluminium Alloy. Skripsi Universitas Sumatera Utara

11. JIS Handbook. 2009. Automobiles - Part and Component. Japanese Standart Association.

12. Surdia, Tata, Saito, S. 2010. Pengetahuan Bahan Teknik. Edisi kesembilan. Jakarta: PT. Pradnya Paramita. 